\title{
Gravity modeling: International trade and R\&D
}

\author{
Dushko Josheski* and Risto Fotov \\ Department of Finance, Faculty of Economics, "Goce Delcev" University, Stip, R. Macedonia.
}

Accepted 22 April, 2013

\begin{abstract}
In this paper, the issue of gravity modeling in international trade was investigated. Standard gravity equation augmented with other variables was used to control for transportation cost, whether trade partners are neighbors and whether country is landlocked, or countries' participants in trade have had colonial history together. Also in this study's model, we control whether traded commodities are homogenous, differentiated or high tech, and referenced. Variables denoting technology are TAl index, which stands for technological achievement index, and which are also used as variables for creation and diffusion of technology, as measured by the number of patents from the residents and royalty, and license fees' receipts by the foreign citizens. The expected results show that trade is highly dependent on the exporters and importers' levels of technology.
\end{abstract}

Key words: Bilateral trade, gravity model, R\&D, OLS, PPML.

\section{INTRODUCTION}

The gravity model has long been recognized for its robustness in explaining many types of international flows, including international trade flows, migration, and others (Pöyhönen, 1963; Bergstrand, 1985). In the gravity model, there exists an analogy in the gravitational attraction between two bodies being determined by their mass and distance between them; bilateral trade flows are essentially determined by the national incomes of the exporting and the importing countries (economic mass), and the distance between them. Analogy with physics is given with the following equation:

$G F=A \frac{M_{1} M_{2}}{D^{2}}$.

Theoretical foundations of this model are in the general equilibrium model of supply and import demand. Assumptions to hold this general equilibrium model is homogenous goods (perfect substitutes):

$$
\begin{aligned}
& Q^{d}=f\left(p, d_{1}, d_{2}, \ldots, d_{n}\right) \\
& Q^{S}=f\left(p, s_{1}, s_{2}, \ldots, s_{m}\right)
\end{aligned}
$$

Here, $Q^{d}$ depends on the price and other factors on the side of the demand, while the supply acts in a similar way. In this system of perfect substitutes, demand and supply of homogenous goods depends on the demand and supply factors, but not on the prices. This is due to the fact that the prices of perfect substitutes are the same in all countries. Prices are endogenous and adjust continuously to equate supply and the demand. This also explains why the gravity modeling data are averaged over several years. Prices temporarily may be high, when the system is in disequilibrium, so this suggests the use of averaged data in order to assure the relevance of the results (Leamer and Stern, 1970). Otherwise, the gravity model is very successful in the empirical literature and has been justified theoretically by Leamer and Stern (1970) and Anderson (1979).

\section{Theoretical link between innovations and trade}

Small open economies have higher marginal utility from openness to trade than large economies (Alesina et al., 1997). Secondly, trade also gives incentive for knowledge spillovers, from developed to less developed economies. Helpman and Coe (1995) found that foreign R\&D has

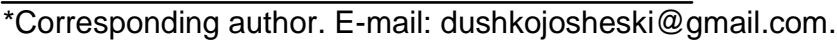


positive effect on the domestic economy, and this effect increases with the increase in openness of the economy. They estimated the following model:

$$
\log T F P_{i}=a_{i}^{0}+a_{i}^{d} \log R \& D_{i}^{d}+a_{i}^{f} m_{i} \log R \& D_{i}^{f}
$$

where, TFP is total factor productivity, $R \& D^{d}$ are domestic innovations, and $R \& D^{f}$ are foreign innovations. Thirdly, trade liberalization increases the market competitiveness and makes domestic firms to innovate more. Final good production in the two countries is assumed to be symmetrical:

$$
\begin{aligned}
& Y_{t}^{*}=\int_{0}^{1} Y_{i t}^{*} d i=\left(L^{*}\right)^{1-a} \int \hat{A}_{i t}^{1-a}\left(x_{i t}^{*}\right)^{a} d i, \quad 0<a<1 \\
& Y_{t}=\int_{0}^{1} Y_{i t} d i=L^{1-a} \int_{0}^{1} \hat{A}_{i t}^{1-a} x_{i t}^{a} d i, \quad 0<a<1
\end{aligned}
$$

The production function with asterisk is foreign country GDP, and that without asterisk is domestic country GDP. If we simplify the output, we will have $Y_{t}=\left(\hat{A}_{i t}^{1-a} x_{i t}^{a}\right) L^{1-a}$, which implies that the price by which the monopolist sells the good is a partial derivative of the previous equation, as such the marginal product of the output

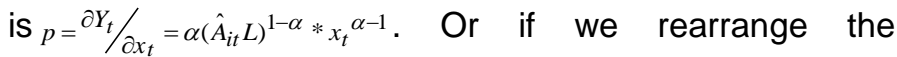
intermediate input, we get $x_{i t}=\hat{A}_{i t} L\left(p_{i t} / a\right)^{\frac{1}{a-1}}$, but if we measure the trade intensity of the domestic economy with foreign trade partners with $\theta^{*}$ and $\theta$, we measure just the openness of the economy. Then, the differential equation is:

$$
\frac{d A}{d t}=-b A+(\theta * \theta)^{\sigma} * v^{\psi}\left(\frac{A^{*}}{A}\right)^{\varepsilon}
$$

Here, $b$ is the technology parameter of $v=\frac{K(t)}{Y(t)}$ and the parameter of $\psi=\frac{\frac{d k}{d t}}{I}$; actually $v^{\psi}$ are per capita investment in $R \& D$, and $\sigma$ is the elasticity of substitution. And if we define $h^{\prime}=(\theta * \theta)^{\sigma} * v^{\psi}$, the differential equation can be presented as: $\frac{\partial A(t)}{\partial t}=\left(h^{\prime} * A(t)^{\varepsilon}\right) * A(t)^{-\varepsilon}-b A(t)$, or the solution of this equation can be given as: $A(t)=C_{1} * e^{-b t}+\frac{h^{\prime}}{b}$. In such a case, technology will not be a factor of convergence to steady-state, but to openness and trade intensity. RiveraBatiz and Romer (1991) introduced human capital into the equation:

$$
Y\left(H_{Y}, L, x\right)=H_{Y}^{\alpha} L^{\beta} \int_{0}^{\infty} x(i)^{1-\alpha-\beta} d i
$$

Here, $\mathrm{H}$ denotes human capital, while $\mathrm{L}$ is labor used in production of technologies. Growth of technology (innovations) is given with the expression: $\frac{\dot{A}}{A}=\varphi^{*} H_{A}$.

\section{DATA AND METHODOLOGY}

This study used data for 13 exporting countries, though bilateral trade data were derived from the study of Feenstra et al. (2005).

The sample of countries was derived from 13 exporter countries (namely: USA, Australia, Japan, Brazil, Bolivia, Chile, China, Czech Republic, Germany, Spain, UK, Ghana and South Africa) and 77 importer countries (Laura and Inmaculada, 2010). We used the data that are present at the centre for International trade data at http://cid.econ.ucdavis.edu/ and Jon Haveman's international trade data web page. Most observations were derived from the paper of Laura and Inmaculada (2010).

World development indicators (2005) were used for derivations of incomes, tariffs were derived from World Integrated Trade Solution (WITS), and Doing business (2006) for transportation costs. Distance between cities and colonial dummies were taken from Jon Haveman's international trade data web page (http://www.macalester.edu/research/economics/page/ha veman/Trade.Resources/Data/Gravity/dist.txt).

The contiguity data are from this website also, and the common language variable is derived from the international trade data web.

TAl index technological achievement index is constructed by the creation of new technology, and diffusion of the new technology variable. The technology and innovations in one country are captured by the number of patents of the residents in the country and the royalty fees and receipts from abroad. The TAl index categorizes the countries into four groups namely: technological leaders (TAl>0.5), potential leaders $(0.35<\mathrm{TAl}<0.49)$, dynamic adopters $(0.19<\mathrm{TAl}<0.34)$, and marginalized (TAl<0.19) (Laura and Inmaculada, 2010). From the estimation techniques used in this study's modulation OLS, Instrumental variable estimation (IV), and PPML-Pseudo Poisson Maximum likelihood models were used to control for heteroscedasticity. In the poison model, $\beta$ coefficient is interpreted as semi elasticity of $\frac{\partial \log E\left(Y_{i} \mathrm{I} x_{i}\right)}{\partial x_{i 1}}=\beta_{1}$

\section{Specifications}

In the international trade, bilateral trade flows are usually explained by the following specification: 
$P X_{i j}=\beta_{0}\left(Y_{i}\right)^{\beta_{1}}\left(Y_{j}\right)^{\beta_{2}}\left(D_{i j}\right)^{\beta_{3}}\left(A_{i j}\right)^{\beta_{4}} u_{i j}$

or, in log - linear formfor OLS estimation

$\ln P X_{i j}=\beta_{0}+\beta_{1} Y_{i}+\beta_{2} Y_{j}+\beta_{3} D_{i j}+\beta_{4} A_{i j}+u_{i j}$

Where:

$P X_{\mathrm{ij}}$ is the U.S. dollar value of the flow from country $i$ to country $\mathrm{j}, \beta_{0}$ is the constant term, $Y_{\mathrm{i}}\left(Y_{\mathrm{j}}\right)$ is the U.S. dollar value of nominal GDP in $i(\mathrm{j}), D_{\mathrm{ij}}$ is the distance from the economic centre of $i$ to that of $\mathrm{j}, A_{\mathrm{ij}}$ is any other factor(s) either aiding or resisting trade between $\mathrm{i}$ and $\mathrm{j}$, and $u_{i j}$ is a log-normally distributed error term with $\mathrm{E}\left(\ln u_{\mathrm{ij}}\right)=0$.

In this study's model, transportation costs for the exporter and the importer, technological achievement index of the exporter and the importer which was used by the UNDP to measure how well a country is diffusing and creating technology, and human skills were also captured. Equation (1) is commonly supplemented by an "adjacency dummy" for a common land border. $A_{\mathrm{ij}}$ typically includes dummy variables for trade associations, which commonly are the best available proxy for trade policy (Bergstrand, 1985: 478). These variables also exist in this study's model. 'This specification was used in Tinbergen (1962); Pöyhönen (1963); Pullainnen (1963); Geraci and Prewo (1977); Prewo (1978) and Abrams (1980). The augmented specification of this study is presented in the following equation; the model also includes dummy variables by the Rauch classification (1999)

http://www.macalester.edu/research/economics/page/hav eman/Trade.Resources/TradeData.html), which codes goods as referenced, homogenous and differentiated. In the OLS equation, we also used human capital variable; this variable was used as proxy for the skills that workers have in exporter and importer countries. There is dummy variable which shows whether countries that participate in the trade are members of North American free trade association (NAFTA), or other countries, or dummy variable that takes value 1 if countries are members of Andean community. Also, the dummy controls whether countries participants in trade had colonial history together, or whether countries are landlocked. Variables are used to control for the diffusion of technology by the importer and exporter, and creation of the new technology by the importer and the exporter. Also the dummy for high tech products is constructed to test how high tech products influence trade:

$$
\begin{aligned}
& P X_{i j}=\beta_{0}+\beta_{1} Y_{i}+\beta_{2} Y_{j}+\beta_{3} D_{i j}+ \\
& \beta_{4} \text { Adj }_{i j}+\beta_{4} \text { Land }_{i}+\beta_{5} \text { land }_{j}+ \\
& \beta_{6} \text { NAFTA }+\beta_{7} C A N+\beta_{8} \text { Lang_off } \\
& +\beta_{9} \text { TAI }_{i}+\beta_{10} \text { TAI }_{j}+\beta_{11} \text { Tarrifs }_{i j}+ \\
& \beta_{12} t c_{i}+\beta_{13} t c_{j}+\beta_{14} \text { high_tech }+ \\
& \beta_{15} \text { homogenousprod }_{k}+ \\
& \beta_{16} \text { ref }_{k}+\beta_{17} \text { differentiated }+ \\
& \beta_{18} \text { heteropgeneity }+u_{i j}
\end{aligned}
$$

tc denotes transportation costs from country $i$ to country $j$, heterogeneity is dummy variable that controls for country heterogeneity, and dummy variable takes the value of 1 when participants in trade are richer than the average sample. Homogenous, differentiated, and high-tech as well referenced products refer to Rauch (1999) classification of products.

\section{RESULTS}

Results from the estimations are reported in the Tables 1 to 3. In Table 1, three models: OLS, IV and Poisson models are reported. Then in the Table 2, IV model with creation of technology variable, and a model with a diffusion of technology are reported. Table 3 shows the effects of homogenous, differentiated, and referenced goods on international trade flows by OLS and PPML model.

From the first three models, exporters' transportation costs are positively and statistically significant in all three models, importers transportation cost have negative sign and they are statistically significant. Income in the exporters and importers' country is positively related to the bilateral trade flows, importers human capital is positively related to trade, and exporter's human capital is negatively correlated with bilateral trade flows. Distance is negatively highly associated with trade $(-0.950)$ and $p$ value $(0.000)$ in the OLS model, while trade and $p$-value is -0.045 and 0.000 respectively in the PPML model. High technology products are negatively associated with trade $(-0.067)$ and $p$-value $(0.000)$, if a country participant in trade is a member of NAFTA, and if the coefficient of elasticity of bilateral trade flows is high (0.864) and significant at all levels of significance. If the trading partners are neighboring countries, the coefficient is very large and positive (0.943), and is highly statistically significant with a p-value of 0.000 . If the importing country is landlocked, the coefficient of elasticity is -1.791 , and highly significant, but if the exporting country is landlocked, the coefficient is -0.062 and highly statistically significant. If trading countries have had colonial history, the coefficient is positive and statistically significant (0.352). Coefficients in the IV and PPML models are similar in size and in sign. There is exception in exporters' human capital due to the fact that the coefficient in OLS model is negative but in PPML model it is positive but of small size (0.086), though it is statistically significant at all levels of significance. Also, the importers' human capital is positive and statistically significant in the OLS model, whereas it is negative and of small size in the PPML model (-0.040). This coefficient is also highly statistically significant. Tariffs in this study's model are positively and statistically significantly correlated with the bilateral trade flows, which is taken as a rather unexpected result. If trading partners are members of Andean community, dummy variable coefficient is positive and statistically significant, which is 
Table 1. OLS, IV and Poisson models.

\begin{tabular}{|c|c|c|c|c|c|c|}
\hline \multirow{2}{*}{ Dependent variable: Bilateral trade } & \multicolumn{2}{|c|}{ OLS model } & \multicolumn{2}{|c|}{ IV model } & \multicolumn{2}{|c|}{ Poison model } \\
\hline & Coefficient & P-value & Coefficient & P-value & Coefficient & P-value \\
\hline $\begin{array}{l}\text { Technological innovation in the exporting } \\
\text { country (R\&D investment) }\end{array}$ & - & - & 2.21 & 0.000 & - & - \\
\hline $\begin{array}{l}\text { Technological innovation in the importing } \\
\text { country (R\&D investment) }\end{array}$ & - & - & 1.65 & 0.000 & - & - \\
\hline Income in the exporter country & 0.911 & 0.000 & 0.54 & 0.000 & 0.045 & 0.000 \\
\hline Income in the importer country & 0.797 & 0.000 & 0.83 & 0.000 & 0.054 & 0.000 \\
\hline Exporters transportation cost & 0.834 & 0.000 & -0.99 & 0.000 & 0.002 & 0.600 \\
\hline Importers transportation cost & -0.651 & 0.000 & -0.77 & 0.000 & -0.045 & 0.000 \\
\hline Distance & -0.950 & 0.000 & -0.72 & 0.000 & -0.051 & 0.000 \\
\hline Tariffs & 0.020 & 0.008 & 0.00 & 0.742 & 0.000 & 0.692 \\
\hline Official common language & 0.683 & 0.000 & 0.34 & 0.000 & 0.034 & 0.000 \\
\hline $\begin{array}{l}\text { Dummy variable }=1 \text { when commodity is } \\
\text { a high-technology commodity, } 0 \\
\text { otherwise }\end{array}$ & -0.047 & 0.000 & -0.07 & 0.000 & -0.004 & 0.000 \\
\hline $\begin{array}{l}\text { Dummy variable }=1 \text { when a commodity } \\
\mathrm{k} \text { is homogeneous, according to Rauch } \\
\text { classification (1999), } 0 \text { otherwise }\end{array}$ & 0.067 & 0.000 & 0.13 & 0.000 & 0.006 & 0.000 \\
\hline $\begin{array}{l}\text { Dummy variable }=1 \text { when a commodity } \\
\mathrm{k} \text { is reference-priced, according to } \\
\text { Rauch } \\
\text { classification (1999), } 0 \text { otherwise }\end{array}$ & 0.005 & 0.6 & 0.03 & 0.002 & 0.001 & 0.105 \\
\hline $\begin{array}{l}\text { Dummy variable it takes the value of } \\
1 \text { when trading partners are richer than } \\
\text { the sample average }\end{array}$ & 0.21 & 0.000 & 0.28 & 0.000 & 0.004 & 0.000 \\
\hline Exporter's human capital & -8.805 & 0.000 & - & - & 0.086 & 0.000 \\
\hline Exporter's human capital squared & 7.621 & 0.000 & - & - & 0.115 & 0.000 \\
\hline Importer's human capital & 1.592 & 0.000 & - & - & -0.040 & 0.000 \\
\hline Importer's human capital squared & -1.134 & 0.000 & - & - & 0.096 & 0.000 \\
\hline $\begin{array}{l}\text { Dummy variable it takes } 1 \text { if countries } \\
\text { are members of North American free } \\
\text { trade association }\end{array}$ & 0.864 & 0.000 & 0.29 & 0.000 & -0.205 & 0.000 \\
\hline $\begin{array}{l}\text { Dummy variable it takes } 1 \text { if countries } \\
\text { are from Andean community }\end{array}$ & 0.019 & 0.638 & - & - & -0.034 & 0.000 \\
\hline
\end{tabular}


Table 1 Contd.

\begin{tabular}{|c|c|c|c|c|c|c|}
\hline $\begin{array}{l}\text { It takes value } 1 \text { if trading countries are } \\
\text { neighbors }\end{array}$ & 0.943 & 0.000 & 1.10 & 0.000 & 0.012 & 0.000 \\
\hline $\begin{array}{l}\text { It takes value } 1 \text { when importing country is } \\
\text { landlocked }\end{array}$ & -1.791 & 0.000 & 1.55 & 0.000 & 0.589 & 0.000 \\
\hline $\begin{array}{l}\text { It takes value } 1 \text { when exporting country is } \\
\text { landlocked }\end{array}$ & -0.062 & 0.000 & $0 . \overline{35}$ & 0.000 & 0.045 & 0.000 \\
\hline $\begin{array}{l}\text { It takes value } 1 \text { if trading countries have had } \\
\text { colonial history together }\end{array}$ & 0.352 & 0.000 & 0.17 & 0.000 & 0.054 & 0.000 \\
\hline Constant & $\begin{array}{c}- \\
23.945\end{array}$ & 0.000 & $\begin{array}{c}- \\
7.39\end{array}$ & 0.000 & 0.002 & 0.600 \\
\hline $\begin{array}{l}\text { R squared and Pseudo R squared for } \\
\text { Poisson model }\end{array}$ & \multicolumn{2}{|c|}{0.79} & \multicolumn{2}{|r|}{0.79} & \multicolumn{2}{|r|}{0.0529} \\
\hline Number of observations & \multicolumn{2}{|c|}{57272} & \multicolumn{2}{|r|}{46440} & \multicolumn{2}{|r|}{58387} \\
\hline
\end{tabular}

Table 2. IV model with creation of technology variable as explanatory variable.

\begin{tabular}{|c|c|c|}
\hline \multirow{2}{*}{ Dependent variable: Bilateral trade } & \multicolumn{2}{|c|}{ OLS model } \\
\hline & Coefficient & P-value \\
\hline Exporter creation of technology & 3.67 & 0.16 \\
\hline Importers creation of technology & 0.31 & 0.06 \\
\hline Income in the exporter country & 0.23 & 0.02 \\
\hline Income in the importer country & 0.93 & 0.00 \\
\hline Exporters transportation cost & -2.00 & 0.08 \\
\hline Importers transportation cost & -0.93 & 0.01 \\
\hline Distance & -0.75 & 0.01 \\
\hline Tariffs & -0.03 & 0.01 \\
\hline Official common language & 0.48 & 0.02 \\
\hline Dummy variable $=1$ when commodity is a high-technology commodity, 0 otherwise & -0.06 & 0.01 \\
\hline $\begin{array}{l}\text { Dummy variable }=1 \text { when a commodity } \mathrm{k} \text { is homogeneous, according to Rauch } \\
\text { classification (1999), } 0 \text { otherwise }\end{array}$ & 0.12 & 0.02 \\
\hline $\begin{array}{l}\text { Dummy variable }=1 \text { when a commodity } \mathrm{k} \text { is reference-priced, according to the classification } \\
\text { of Rauch (1999), } 0 \text { otherwise }\end{array}$ & 0.03 & 0.01 \\
\hline $\begin{array}{l}\text { Dummy variable takes the value of } 1 \text { when trading partners are richer than the sample } \\
\text { average }\end{array}$ & 0.64 & 0.02 \\
\hline Dummy variable takes 1 if countries are members of North American free trade association & 3.67 & 0.16 \\
\hline It takes value 1 if trading countries are neighbors & 0.19 & 0.06 \\
\hline It takes value 1 when importing country is landlocked & 1.15 & 0.04 \\
\hline It takes value 1 when exporting country is landlocked & (omitted) & n.a. \\
\hline It takes value 1 if trading countries have had colonial history together & -0.17 & 0.02 \\
\hline Constant & -0.12 & 0.02 \\
\hline R squared & \multicolumn{2}{|c|}{0.76} \\
\hline Number of observations & \multicolumn{2}{|c|}{50600} \\
\hline
\end{tabular}


Table 3. Diffusion of a new technology model.

\begin{tabular}{lcc}
\hline \multirow{2}{*}{ Dependent variable: Bilateral trade } & \multicolumn{2}{c}{ OLS model } \\
\cline { 2 - 3 } & Coefficient & P-value \\
\hline Diffusion of recent technology by exporting country & 3.668 & 0.000 \\
Diffusion of recent technology by importing country & 0.307 & 0.000 \\
Income in the exporter country & 0.234 & 0.000 \\
Income in the importer country & 0.934 & 0.000 \\
Exporters transportation cost & -1.997 & 0.000 \\
Importers transportation cost & -0.928 & 0.000 \\
Distance & -0.746 & 0.000 \\
Tariffs & -0.031 & 0.000 \\
Official common language & 0.485 & 0.000 \\
Dummy variable it takes the value of 1 when trading partners are richer than the sample & -0.064 & 0.000 \\
average & & 0.000 \\
Dummy variable it takes 1 if countries are members of North American free trade & 0.120 & 0.000 \\
association & 0.032 & 0.005 \\
It takes value 1 if trading countries are neighbors & 0.644 & 0.000 \\
It takes value 1 when importing country is landlocked & 0.188 & 0.001 \\
It takes value 1 when exporting country is landlocked & 1.147 & 0.000 \\
It takes value 1 if trading countries have had colonial history together & 7.463 & 0.000 \\
Constant & & 0.77 \\
R squared & & 40204 \\
Number of observations
\end{tabular}

true also if trading countries are richer than the average of the sample (that is, if there is heterogeneity in the trade). If homogenous products are trade coefficient on the bilateral trade elasticity, it is positive and statistically significant at 0067, and if the products are referenced according to the classification of Rauch (1999), the coefficient is positive and statistically significant. Table 2 shows the augmented model with the creation of technology as explanatory variable.

In this model, signs of the variables are expected to be similar to those of the previous model in which exporters and importers' cost was interpreted to have negative sign, while importers and exporters' income was interpreted to have positive elasticity with bilateral trade. Tariffs here as expected are negatively related with trade flows, exporters creation of technology is positively associated with bilateral trade (3.67), and importers creation of new technology is positive (0.31) and statistically significant. Table 3 presents the augmented model with diffusion of technology.

In this model signs of the variables are expected to be similar to those of the previous model in which exporters and importers' cost was interpreted to have negative sign, while importers and exporters' income was interpreted to have positive elasticity with bilateral trade. Tariffs here as expected are negatively related with trade flows, exporters capability for diffusion of technology is positively associated with bilateral trade (3.67), and ability for diffusion of new technology is positive (0.307) and statistically significant. Table 4 presents the augmented model with referenced products, differentiated products, homogenous products, and their influence on bilateral trade flows.

TAl index in all 6 models is positive and statistically significant; however, importers' TAI and exporters' TAI share a common sign (+). Referenced priced products have positive and statistically significant sign when regressed with bilateral trade flows. On the other side, trade with differentiated products is negatively associated with bilateral trade. Moreover, homogenous products have expected positive sign in association with bilateral trade.

\section{Conclusion}

Gravity model once again proved to be a useful technique when international trade bilateral trade flows is studied. As shown in the theory, we proved that innovations are highly associated with trade, though for policy makers, the important conclusion is that they must enhance trade with investment in R\&D. Innovations are trade promoting variables in the findings of this study. Government consumption is negatively associated with growth usually, but fiscal policy can enhance promotion of R\&D and therefore promote exports for the country where this policy has been applied. From the regression 
Table 4. Referenced, differentiated and homogenous products.

\begin{tabular}{|c|c|c|c|c|c|c|c|c|c|c|c|c|}
\hline \multirow{3}{*}{$\begin{array}{l}\text { Types of products } \\
\text { Models } \\
\text { Dependent variable: } \\
\text { Bilateral trade } \\
\end{array}$} & \multicolumn{4}{|c|}{ Referenced products } & \multicolumn{4}{|c|}{ Differentiated products } & \multicolumn{4}{|c|}{ Homogenous products } \\
\hline & \multicolumn{2}{|c|}{ OLS model } & \multicolumn{2}{|c|}{ Poisson model } & \multicolumn{2}{|c|}{ OLS model } & \multicolumn{2}{|c|}{ Poisson model } & \multicolumn{2}{|c|}{ OLS model } & \multicolumn{2}{|c|}{ Poisson model } \\
\hline & Coef. & P-value & Coef. & P-value & Coef. & P-value & Coef. & P-value & Coef. & P-value & Coef. & P-value \\
\hline $\begin{array}{l}\text { Technological innovation } \\
\text { in the exporting country } \\
\text { (R\&D investment) }\end{array}$ & 4.82 & 0.000 & 0.34 & 0.00 & 4.82 & 0.000 & 0.34 & 0.000 & 4.9 & 0.000 & 0.345 & 0.000 \\
\hline $\begin{array}{l}\text { Technological innovation } \\
\text { in the importing country } \\
\text { (R\&D investment) }\end{array}$ & 2.92 & 0.000 & 0.21 & 0.00 & 2.91 & 0.000 & 0.21 & 0.000 & 2.92 & 0.000 & 0.206 & 0.000 \\
\hline $\begin{array}{l}\text { Dummy variable = } 1 \text { when } \\
\text { a commodity } k \text { is } \\
\text { reference-priced, } 0 \\
\text { otherwise }\end{array}$ & 0.09 & 0.000 & 0.01 & 0.01 & - & - & - & - & - & - & - & - \\
\hline $\begin{array}{l}\text { Dummy variable = } 1 \text { when } \\
\text { a commodity } k \text { is } \\
\text { differentiated, } 0 \text { otherwise }\end{array}$ & - & - & - & - & -0.110 & 0.000 & -0.01 & 0.00 & - & - & - & - \\
\hline $\begin{array}{l}\text { Dummy variable = } 1 \text { when } \\
\text { a commodity } k \text { is } \\
\text { homogenous, } 0 \text { otherwise }\end{array}$ & - & - & - & - & - & - & - & - & 0.120 & 0.000 & 0.008 & 0.060 \\
\hline Constant & 10.92 & 0 & 2.42 & 0 & 11.03 & 0.00 & 2.42 & 0.00 & 10.94 & 0 & 2.417 & 0 \\
\hline $\begin{array}{l}R \text { squared and pseudo } R \\
\text { squared for Poisson } \\
\text { regression }\end{array}$ & \multicolumn{2}{|c|}{0.36} & \multicolumn{2}{|c|}{0.0239} & \multicolumn{2}{|c|}{0.359} & \multicolumn{2}{|c|}{0.0239} & \multicolumn{2}{|c|}{0.3587} & \multicolumn{2}{|c|}{0.0239} \\
\hline Number of observations & \multicolumn{2}{|c|}{67365} & \multicolumn{2}{|c|}{67365} & \multicolumn{2}{|c|}{67365} & \multicolumn{2}{|c|}{67365} & \multicolumn{2}{|c|}{67365} & \multicolumn{2}{|c|}{67365} \\
\hline
\end{tabular}

results also, the greatest impediments for international trade are: the distance between countries, importers' transportation costs, and if trading partners are landlocked.

\section{REFERENCES}

Abrams (1980). International trade Flows under Flexible Exchange rates, Economic Review of the Federal Reserve Bank of Kansas City, 65(3): 3-10.

Alesina A, Spolaore E, Wacziarg R (1997). Economic integration and politic disintegration, 
NBER working paper

Anderson JA (1979). Theoretical Foundation for the Gravity Equation. Am. Econ. Rev., 63: 106-116.

Bergstrand $J$ (1985). The Gravity Equation in International Trade. Rev. Econ. Stat., 67(3): 474-481.

Coe, Helpman (1995). "International R\&D Spillovers" Eur. Econ. Rev., 39(5): 859-887.

Laura M, Inmaculada M (2010). "The Effect of Technological Innovation on International Trade. A Nonlinear Approach [Dataset]", http://hdl.handle.net/1902.1/14520 Economics: The Open-Access, Open-Assessment E-Journal [Distributor] V1 [Version]

Leamer E, Stern R (1970). Quantitative International Economics (Boston: Allyn and Bacon).
Pöyhönen P (1963). A Tentative Model for the Volume of Trade between Countries, Weltwirtschaftliches Archive, 90(1): 93-100.

Rivera-Batiz, Romer P (1991). "International Trade with Endogenous Technical Change."Eur. Econ. Rev., 35: 971-1004. 